\title{
Manajemen Anestesi Operasi Total Tiroidektomi Menggunakan Target Controlled Infusion (TCI) Propofol dan Blok Pleksus Servikal Superfisial pada Pasien Karsinoma Tiroid dengan Metastasis Paru
}

Anesthesia Management Operations Total thyroidectomy Using Target Controlled Infusion (TCI) of propofol and Superficial Cervical Plexus Block on Thyroid Carcinoma Patients with Lung Metastasis

Dedy Fachrian $\varangle^{*}$, Widya Istanto**, M. Sofyan Harahap**

* Residen Bagian Anestesi dan Terapi Intensif Universitas Diponegoro/ RSUP Dr. Kariadi

** Staff Pengajar Bagian Anestesi dan Terapi Intensif Universitas Diponegoro/ RSUP Dr. Kariadi

$\triangle$ Korespondensi / correspondencededyfachrian@gmail.com

\section{ABSTRACT}

Background: Malignancies of the thyroid are rare, but thyroid cancer is the most common endocrine malignancy. Lung cancer appear when genetic mutations occur in normal cells in the lungs or metastasis from elsewhere, such as breast, thyroid, or large intestine. Thyroid malignancy poses some challenges in anesthesia such as possible difficulties in airway management and the possibility of a thyroid storm. Mass in the lungs make anesthetic management of these patients become more complex.

Case: Woman 36 years old with pulmonary metastases of thyroid carcinoma was planned for total thyroidectomy. From the preoperative examination found a lump in the right neck around a ball jacks size. Patients were in clinically and laboratory euthyroid condition. From the $x$-ray photo found mass in the chest with opacity rounded shape, relative boundary edges firmly with calcification in the left hemithorax.

Anesthesia management begins with midazolam $2 \mathrm{mg}$ as premedication followed by TCI Propofol plasma target of $6 \mathrm{mcg} / \mathrm{ml}$, Fentanyl $100 \mathrm{mcg}$ and rocuronium $30 \mathrm{mg}$ for induction and then intubated without hemodynamic fluctuation. After that, the superficial cervical plexus block was done using $0.25 \%$ bupivacaine concentrations of 10 cc volume on each side of the neck. For maintenance TCI target plasma lowered to $4 \mathrm{mcg} / \mathrm{ml}$ and intermittent rocuronium.

Cycle Pressure ventilator was set to avoid lung hyperinflation with $\mathrm{O} 2$ and air ratio of 1: 1 without using N2O and Volatile Anesthetic. Surgery was 4 hours with stable hemodynamic. At the end of the operation TCI Propofol was reduced gradually and patients at was extubated after adequately spontaneous breathing then the patient returned to the ward.

Summary: The use of a combination of general anesthesia with intubation using 
Propofol TCI and can be superficial cervical block anesthesia technique choice in cases of goitre with lung tumors. Analgesia through the superficial cervical plexus block proved to be quite satisfactory during surgery.

Keywords: thyroid carcinoma, TCI Propofol, superficial cervical plexus block

\section{ABSTRAK}

Latar Belakang: Keganasan pada tiroid jarang terjadi, namun kanker tiroid merupakan keganasan endokrin yang paling sering terjadi. Kanker paru-paru muncul ketika terjadi mutasi genetik pada sel normal dalam paru-paru yang dapatbermetastasis ke seluruh tubuh atau juga dapat diakibatkan metastasis dari tempat lain, seperti payudara, tiroid, atau usus besar. Keganasan tiroid menimbulkan beberapa tantangan dalam tindakan anestesi yaitu kemungkinan kesulitan dalam pengelolaan jalan nafas dan kemungkinan terjadinya badai tiroid.Adanya massa pada paru menjadikan pengelolaan anestesi pada pasien ini menjadi lebih kompleks.

Kasus: Wanita usia 36 tahun dengan karsinoma tiroid metastasis paru direncanakan tindakan total tiroidektomi. Dari pemeriksaan pra operasi didapatkan keluhan benjolan pada leher kanan sebesar bola bekel. Pasien berada dalam Kondisi eutiroid secara klinis dan laboratoris. Dari foto dada didapatkan massa dengan opasitas bentuk bulat, batas relatif tegas dengan kalsifikasi di tepinya pada hemithoraks kiri.

Manajemen anestesi diawali dengan midazolam 2 mg sebagai premedikasi dilanjutkan dengan TCI Propofol target plasma $6 \mathrm{mcg} / \mathrm{ml}$, Fentanyl $100 \mathrm{mcg}$ dan Rocuronium $30 \mathrm{mg}$ untuk induksi kemudian pasien diintubasi tanpa gejolak hemodinamik. Setelah itu, dilakukan blok pleksus servikal superfisial dengan bupivacaine konsentrasi 0,25\% volume 10 cc di setiap sisi leher.Untukrumatantarget plasma TCI diturunkan menjadi $4 \mathrm{mcg} / \mathrm{ml}$ dan rocuronium intermiten.

Ventilator dengan setting Pressure Cycle untuk menghindari hiperinflasi paru dengan $\mathrm{O}_{2}$ dan Air dengan perbandingan 1:1 tanpa menggunakan $\mathrm{N}_{2} \mathrm{O}$ dan Agen Anestesi Volatile. Operasi berlangsung selama 4 jam dengan hemodinamik stabil.

Pada akhir operasi TCI Propofol diturunkan secara bertahap dan pasien diekstubasi setelah pernapasan spontan adekuat kemudian pasien kembali ke ruang perawatan.

Ringkasan: Penggunaan kombinasi anestesi umum dengan intubasi menggunakan TCI Propofol dan blok servikalis superfisial dapat menjadi teknik anestesi pilihan pada kasus struma disertai tumor paru. Analgesi melalui blok pleksus servikal superfisial terbukti cukup memuaskan selama operasi.

Kata Kunci: Karsinoma tiroid, TCI Propofol, Blok pleksus servikal superfisial. 


\section{PENDAHULUAN}

Kanker tiroid bianya timbul pada nodul tiroid asimptomatik yang sudah ada sebelumnya. Keganasan ini jarang terjadi, didapatkan insidensi 7 per 100.000 populasi setiap tahun. Namun demikian, kanker tiroid merupakan keganasan endokrin yang paling sering terjadi. Secara klinis nodul tiroid didapatkan pada $4-7 \%$ populasi dewasa dan paling sering terjadi pada wanita. ${ }^{1}$

Karsinoma tiroid tipe papiler merupakan karsinoma tiroid paling sering ditemukan meliputi hampir $80 \%$ dari seluruh kasus. Usia pasien biasanya pada dekade ke 3 sampai ke 5 . Karsinoma ini secara makroskopis berbentuk padat, ireguler ataupun kistik yang timbul dari epitel folikular. Masa tumor tidak berkapsul tetapi berbatas tegas. Secara mikroskopis. tampak pertumbuhan epitel berjonjot - jonjot. ${ }^{1}$

Kanker paru-paru muncul ketika terjadi mutasi genetik pada sel normal dalam paru-paru. Akibatnya, sel menjadi tidak normal dalam bentuk dan perilaku, dan mereproduksi tanpa henti. Sel-sel yang abnormal membentuk tumor yang jika tidak diangkat dengan operasi dapat menginvasi pembuluh darah serta kelenjar getah bening kemudian menyebar ke daerah sekitas dan pada akhirnya menyebar (bermetastasis) ke seluruh tubuh. Selain itu, kanker di paru-paru mungkin akibat metastasis dari tempat lain, seperti payudara, tiroid, atau usus besar. $^{2}$

Salah satu penatalaksaan dari kanker tiroid adalah tiroidektomi. Indikasi untuk tiroidektomi adalah keganasan tiroid, gejala obstruktif, gondok retrosternal, penyakit Graves yang tidak responsif terhadap pengobatan medis, hipertiroidisme berulang, penyakit Hashimoto dan untuk alasan kosmetik. $^{3}$

Keganasan tiroid menimbulkan beberapa kesulitan dalam tindakan anestesi yaitu kemungkinan kesulitan dalam pengelolaan jalan nafas dan kemungkinan terjadinya badai tiroidwalaupun hal ini jarang terjadi. ${ }^{4}$ Adanya massa pada paru menjadikan pengelolaan anestesi pada pasien ini menjadi lebih kompleks.

\section{KASUS}

Wanita usia 36 tahun dengan karsinoma tiroid metastasis paru direncanakan tindakan total tyroidektomi. Dari pemeriksaan pra operasi didapatkan keluhan benjolan pada leher kanan sebesar bola bekel yang semakin membesar. Pasien juga mengeluhkan batuk dengan intensitas sering, tidak berdahak dan tidak mengeluarkan darah. Pasien merasa cepat lelah jika beraktivitas dan hanya dapat melakukan aktivitas ringan dan sedang. Pasien menyangkal keluhan sulit menelan, perubahan suara, tidur mengorok.

Dari pemeriksaan fisik didapatkan tanda vital dalam batas normal, massa pada leher kanan sebesar bola bekel dan, deviasi trakhea minimal ke 
kiri. Pemeriksaan fisik paru didapatkan suara nafas vesikuler dan ronkhi minimal di paru kiri. Dari penilaian index wayne pasien berada pada eutiroid. Pemeriksaan darah rutin, fungsi ginjal dan hormon tiroid didapatkan dalam batas normal.

Penilaian jalan nafas pada pasien ini dari pemeriksaan luar didapatkan massa pada leher sebelah kanan sebesar bola bekel dan deviasi trakhea minimal ke kiri, dari evaluasi 33-2: pasien dapat buka mulut lebih dari 3 jari, jarak di antara ujung mentum dan persimpangan mandibula-leher 3 jari dan jarak di antara persimpangan mandibula-leher dan tiroid notch2 jari. Dari penilaian Mallampati pasien masuk dalam kategori I. Tidak ditemukan tandatanda obstruksi saluran nafas dan mobilitas leher yang baik.

Pemeriksaan foto dada menunjukkan adanya massa dengan opasitas bentuk bulat, batas relatif tegas dengan kalsifikasi di tepinya pada hemithoraks kiri setinggi korpus vertebarae thorakal 10-12.

Pada hari operasi pasien diberikan premedikasi midazolam $2 \mathrm{mg}$. Induksi dengan propofol menggunakan TCI dengan target konsentrasi plasma di setting $6 \mathrm{mcg} / \mathrm{ml}$. Setelah tertidur diberikan rocuronium $3 \mathrm{mg}$ dan fentanyl $100 \mathrm{mg}$. Setelah didapatkan kedalaman anestesi yang cukup, dilakukan Intubasi dan tidak didapatkan kesulitan maupun gejolak hemodinamik.Setelah itu dilakuan blok servikalis superfisial dengan bupivacaine $0,25 \%$ dengan vol- ume 10cc pada tiap sisi leher.

Dari inspeksi dinilai pengembangan paru yang cukup pada settingventilator dengan presure cycle, PEEP 4 dan frekuansi $12 \mathrm{x} /$ menit. Diberikan campuran $\mathrm{O}_{2}$ dan Air dengan perbandingan 1:1. Rumatan dengan propofol TCI terget $4 \mathrm{mcg} / \mathrm{ml}$ dan rocuronium intermittent.

Operasi dilakukan selama 4 jam dan menjelang selesai operasi dilakukan pemeriksaan BGA dan didapatkan hasil dalam batas normal. Ketika operator melakukan jahitan terakhir pada kulit, target propofol TCI secara bertahap dikurangi sampai di stop dan pasien mulai di weaning dari ventilator. Pasien di ekstubasi setelah didapatkan nafas spontan yang adekuat kemudian di observasi di ruang pemulihan.

Setelah 1 jam observasi, hemodinamik pasien dinilai baik dan tidak didapatkan tanda-tanda obstruksi jalan nafas kemudian diputuskan kembali ke ruang perawatan. Di ruang perawatan tidak didapatkan keluhan yang berarti dan pasien dipulangkan pada hari ke 3 post operasi.

\section{PEMBAHASAN}

Pasien dengan struma harus dievaluasi untuk kemungkinan kesulitan pengelolaan jalan napas dan deviasi trakea. ${ }^{4}$ Biasanya operasi dilakukan dengan intubasi endotrakeal. Penilaian untuk kemungkinan adanya kesulitan untuk laringoskopi dan intubasi dapat dinilai dengan kriteria $L E M O N .^{5}$

Untuk penilaian jalan nafas pada 
pasien ini dari pemeriksaan luar didapatkan massa pada leher sebelah kanan sebesar bola bekel dan deviasi trakhea minimal ke kiri, dari evaluasi 3 -3-2: pasien dapat buka mulut lebih dari 3 jari, jarak di antara ujung mentum dan persimpangan mandibulaleher 3 jari dan jarak di antara persimpangan mandibula-leher dan tiroid notch2 jari. Dari penilaian Mallampati pasien masuk dalam kategori I. Tidak ditemukan tanda-tanda obstruksi saluran nafas dan mobilitas leher yang baik. Sehingga dapat disimpulkan bahwa diperkirakan tidak ditemui kesulitan untuk laringoskopi dan intubasi.

Semua prosedur bedah elektif, termasuk subtotal tiroidektomi harus ditunda sampai pasien euthyroid secara klinis dan laboratoris. ${ }^{6}$ Dari evaluasi praanestesi pasien berada pada kondisi eutiroid baik secara klinis yang dinilai dari index wayne dan laboratoris dimana kadar T3, T4 dan TSH pasien berada dalam batas normal.

Adanya massa tumor pada paru yang didapatkan dari pemeriksaan foto dada membutukan pengelolaan anestesi yang berbeda. Massa tumor dapat menyebabkan obstruksi pada saluran nafas di paru dan harus diperkirakan adanya kerapuhan pada massa tersebut. ${ }^{7,8}$ Selain itu harus diperkirakan juga adanya perubahan dari pertukaran gas di paru akibat tumor ini sehingga penggunaan agen anestesi volatile dihindari. Salah satu tekhnik anestesia pilihan pada kondisi dimana akses terhadap jalan nafas terbatas ada- lah dengan $\mathrm{TCI}^{9}{ }^{9}$ oleh kerena itu anestesi umum dengan menggunakan TCI propofol untuk induksi dan rumatan anestesi menjadi pilihan pada kasus ini.

TCI adalah sebuah cara infusi terkendali dengan tujuan mencapai target konsentrasi obat yang telah ditentukan dalam kompartemen tubuh atau jaringan tertentu. Sistem TCI merupakan suatu sistem yang diprogram berdasarkan farmakokinetik dan farmakodinamik obat yang digunakan untuk menghitung dan memperkirakan konsentrasi dari obat yang diberikan baik di dalam plasma atau jaringan tertentu. ${ }^{9}$

Propofol merupakan obat anestesi pertama dan tersering digunakan dengan sistem TCI. Model farmakokinetik propofol pasien dewasa yang paling banyak digunakan adalah model Marsh. Model Marsh merupakan pengembangan dari model farmakokinetik propofol oleh Gepts dengan memperhitungkan volume kompartemen sentral sebagai sebuah fungsi linear terhadap berat badan pasien. ${ }^{9}$

Induksi pada pasien ini menggunakan TCI propofol dimulai dengan setting target $6 \mathrm{mcg} / \mathrm{ml}$ dan didapatkan kedalaman ansetesia yang cukup tanpa adanya hipotensi. Dilanjutkan dengan pemberian fentanyl dan rocuronium kemudian pasien di intubasi tanpa gejolak hemodinamik. Ventilator di setting dengan Pressure Cycle untuk menghindari hiperinflasi dari paru-paru. Hiperinflasi 
dari paru-paru akibat ventilasi tekanan positif yang diberikan pada pasien tumor paru dapat mengakibatkan Air Trapping dengan katub yang mengakibatkan kondisi tension pnemothorax. Jika hal ini terjadi akan mengakibatkan peningkatan tekanan intratorakal dan mengurangi aliran balik vena ke jantung yang pada akhirnya menurunkan cardiac output. ${ }^{7}$

$$
\text { Penggunaan } \mathrm{N}_{2} \mathrm{O} \text { juga }
$$

sebaiknya dihindari pada pasien tumor paru karena gas ini dapat berdifusi ke dalam tumor atau ke jaringan paru di sektarnya dan menimbulkan tension pneumothorax. ${ }^{7,8}$ Untuk manajemen nyeri selama operasi di lakukan tekhnik regional anestesia cervikal superfisial blok. Dimana tekhnik ini dapat digunakan pada tindakan tyroidektomi namun dengan komplikasi yang dapat terjadi berupa blok nervus phrenikus bilateral. ${ }^{3}$ Selain itu tekhnik ini dipilih dengan pertimbangan lokasi penyuntikan tidak tertutup massa tumor, titik-titik anatomis untuk lokasi penyuntikan dapat diidentifikasi dengan baik pada pasien ini, mengurangi penggunaan opioid dan lebih ekonomis.

Menurut Mukhopadhyay sandip, blok pleksus servikal superfisial dinilai cukup untuk menghasilkan anestesi di bagian anterior dan anterolateral leher. Dia juga mengungkapkan bahwa blok ini tampaknya menjadi alternatif yang murah, aman, dan efektif untuk anestesi umum konvensional. ${ }^{10}$ Hal yang sama juga dinyatakan oleh Andrieu $\mathrm{G}$ bahwa blok ini efektif da- lam mengurangi kebutuhananalgesiksetelahoperasi tiroid. ${ }^{11}$

Untuk rumatan TCI Propofol, target plasma diturunkan menjadi 4 $\mathrm{mcg} / \mathrm{ml}$ dan didapatkan hemodinamik yang stabil serta kedalaman anestesi yang cukup selama operasi. Blok servikalis superfisial memberikan analgesia yang baik selama operasi.

\section{RINGKASAN}

Pengelolaan anestesi pada pasien struma disertai tumor paru membutuhkan beberapa perimbangan khusus yaitu pasien harus berada dalam kondisi eutiroid secara klinis dan laboratoris, kedalaman anestesi harus dijaga cukup dalam untuk tindakan intubasi dan selama operasi, cegah terjadinya hiperinflasi paru, penggunaan agen anestesi volatile dan $\mathrm{N}_{2} \mathrm{O}$ sebaiknya dihindari.

Penggunaan kombinasi TCI Propofol dan blok servikalis superfisial dapat menjadi tekhnik anestesi pilihan pada kasus struma disertai tumor paru. Analgesi melalui blok pleksus servikal superfisial terbukti cukup memuaskan selama operasi.

\section{DAFTAR PUSTAKA}

1. Harahap Wirsma Arif. Keganasan Pada Kelenjar Tiroid. Dalam: Suplemen Majalah Kedokteran Andalas. 2010. P. 34

2. Harvey Simon. Non-small cell lung cancer. 2013.avaible from URL: http://umm.edu/health/medical/ reports/articles/nonsmall-cell-lungcancer

3. Farling Peter. Thyroid Disease. In: 
Hall George, Hunter Jennifer, Cooper Mark. Core Topics in Endocrinology in Anesthesia and Critical Care. New York: Cambridge University Press; 2010. P. 17-9

4. Singer Emily, Sikka Pankaj. Thyroid Disorders. In: Vavanti Charles, Sikka Pankaj, Urman Richard, Dershwitz Mark, Segal Scott. Essantial Clinical Anesthesia. New York: Cambridge University Press; 2010. P. 662

5. Zafirova Zdravka, Tung Avery. The Difficult Airway: Definitions and Algorithms. In: Glick David B, Cooper Richard M, Ovassapian Andranik. The Difficult Airway An Atlas of Tools and Techniques for Clinical Management. New York: Springer; 2013. P. 1-3

6. Anesthesia for Patients with Endocrine Disease. In: Butterworth John, Mackey David, Wasnick John. In: Morgan and Mikhail's Clinical Anesthesiology. United States: Mc Graw Hil Education; 2013. P.734

7. Ross Nicki, McCormick Bruce. Thoracic Surgery. In: Allman Keith, Wilson Ian. Oxford Handbook of Anaesthesia. New York: Oxford
University Press; 2011. P.367

8. Ruzzeh Sharif, Kurup Viji. Respiratory Disease In:Hines roberta, Marschall Katherine. Stoelting's Anesthesia dan Co-Existing Disease. Philadelphia: Elsevier Saunders; 2012. P.209

9. Adhrie Sugiarto. Panduan Praktis Total Intravenous Anesthesia dan Target Controlled Infusion. PP PERDATIN; 2012. P.33-5

10. MukhopadhyaySandip,NiyogiMausumi, DuttaManotosh, Ray Ritam, Gayen Ganesh Chandra, MukherjeMonoj, et all. Bilateral superficial cervical plexus block with or without lowdose intravenous ketamine analgesia: effective, simple, safe, and cheap alternative to conventional general anesthesia for selected neck surgeries. Local and Regional Anesthesia 2012:5 1-7

11. G. Andrieu, H. Amrouni, E. Robin, B. Carnaille, J. M. Wattier, F. Pattou,et all. Analgesic efficacy of bilateral superficial cervical plexus block administered before thyroid surgery under general anaesthesia. Br J Anaesth. 2007: 1-6 